\title{
Burden of SARS-CoV-2 infection among nursing professionals in Brazil
}

\author{
Carga da infecção pelo SARS-CoV-2 entre os profissionais de enfermagem no Brasil \\ Carga de la infección por SARS-CoV-2 entre los profesionales de enfermería en Brasil
}

Roberto Carlos Lyra da Silva'
ORCID: 0000-0001-9416-9525
Daniel Aragão Machado'
ORCID: 0000-0003-0680-5291

Antônio Augusto de Freitas Peregrino" ORCID: 0000-0002-6617-480X

Cristiano Bertolossi Marta" ORCID: 0000-0002-0635-7970

Thiago Quinellato Louro"II ORCID: 0000-0001-8371-628X

Carlos Roberto Lyra da Silva' ORCID: 0000-0002-4327-6272

'Universidade Federal do Estado do Rio de Janeiro. Rio de Janeiro, Rio de Janeiro, Brazil. "Universidade do Estado do Rio de Janeiro. Rio de Janeiro, Rio de Janeiro, Brazil. I" Universidade Federal Fluminense. Rio das Ostras, Rio de Janeiro, Brazil.

How to cite this article:

Silva RCL, Machado DA, Peregrino AAF, Marta CB, Louro TQ, Silva CRL. Burden of SARS-CoV-2 infection among nursing professionals in Brazil. Rev Bras Enferm. 2021;74(Suppl1):e20200783. doi: http://dx.doi.org/10.1590/0034-7167-2020-0783

Corresponding author: Roberto Carlos Lyra da Silva E-mail: roberto.c.silva@unirio.br

EDITOR IN CHIEF: Dulce Barbosa ASSOCIATE EDITOR: Álvaro Sousa

\section{ABSTRACT}

Objective: Estimate the burden of SARS-CoV-2 infection among nursing professionals in Brazil. Method: Ecological study using data from the Nursing Observatory. The weight attributed to diseases was based on the Global Disease Burden Study 2017, considering the lower respiratory infection as moderate. Results: 7,201 records were analyzed; and, 190 deaths were recorded. The total number of years of life adjusted for disability was 5,825.35 years, with an average of $2,912.76(95 \% \mathrm{Cl} 2,876.49-2,948.86)$. The adjusted rate per thousand professionals was 1,475.94 years for men and 674.23 years for women. Conclusion: SARSCoV-2 infection in Brazil follows an upward trend in nursing and has a major impact among women, nursing technicians and younger professionals.

Descriptors: Pandemics; COVID-19; Disease Burden; Nursing; Quality of Life; Disability Adjusted Life Years.

\section{RESUMO}

Objetivo: Estimar a carga da infecção pelo SARS-CoV-2 entre os profissionais de enfermagem no Brasil. Método: Estudo ecológico utilizando dados do Observatório da Enfermagem. O peso atribuído a doenças teve como referência o Estudo de Carga de Doença Global de 2017, considerando a infecção respiratória de vias inferiores moderada. Resultados: Foram analisados 7.201 registros; e, contabilizados 190 óbitos. O número total de anos de vida ajustados por incapacidade foi de 5.825,35 anos, com média de 2.912,76 (IC 95\% $2.876,49-2.948,86)$. A taxa ajustada por mil profissionais foi de 1.475,94 anos para os homens e 674,23 anos para as mulheres. Conclusão: A infecção pelo SARS-CoV-2 no Brasil segue uma tendência de alta na enfermagem e tem grande impacto entre as mulheres, técnicos de enfermagem e profissionais mais jovens.

Descritores: COVID-19; Carga da Doença; Enfermagem; Qualidade de Vida; Anos de Vida Ajustados pela Incapacidade.

\section{RESUMEN}

Objetivo: Estimar la carga de la infección por SARS-CoV-2 entre los profesionales de enfermería en Brasil. Método: Estudio ecológico utilizando datos del Observatorio de Enfermería. El peso atribuido a enfermedad tuvo como referencia el Estudio de Carga de Enfermedad Global de 2017, considerando la infección respiratoria de vías inferiores moderada. Resultados: Han sido analizados 7.201 registros; $y$, contabilizados 190 óbitos. El número total de años de vida ajustados por discapacidad fue de 5.825,35 años, con mediana de $2.912,76$ (IC 95\% $2.876,49-2.948,86)$. La tasa ajustada por mil profesionales fue de $1.475,94$ años para los hombres y 674,23 años para las mujeres. Conclusión: La infección por SARS-CoV-2 en Brasil sigue una tendencia de alta en la enfermería y hay gran impacto entre las mujeres, técnicos de enfermería y profesionales más jóvenes.

Descriptores: Pandemias; COVID-19; Carga de enfermedad; Enfermería; Calidad de Vida; Años de Vida Ajustados por Discapacidad. 


\section{INTRODUCTION}

COVID-19 is a new viral disease that has caused health systems worldwide to collapse, partly because of the high number of casualties among health professionals, especially nursing professionals. The burden attributable to the disease in terms of morbidity and mortality and quality of life or disabilities.

The SARS-CoV-2 virus, of the Coronaviridae family, was identified in China in December 2019, in the city of Wuhan, Hubei province, which quickly became the epicenter of a pandemic allegedly linked to the "new coronavirus associated with acute respiratory syndrome severe" (SARS CoV-2), which causes infectious disease by coronavirus-2019 (COVID-19)(1).

About $15 \%$ of COVID-19 cases become serious; and, on the frontline of combating the disease, health professionals are also among those directly affected by the pandemic, with many of them becoming fatal victims ${ }^{(2)}$.

Studies suggest that environmental contamination, due to the elimination of respiratory strays in individuals with SARS-CoV-2, whether symptomatic or not, can make the environment, especially the hospital, a potential means of transmission. In this context, health professionals were quickly recognized as a high risk group for infection ${ }^{(3)}$.

SARS-CoV-2 infection has revealed to the world frightening and dramatic numbers related to loss of life. In Brazil, between March and June 2020, 432,668 health professionals performed the COVID-19 test in the country. Of these, 83,118 tested positive, and 189,788 are being analyzed. 169 deaths of these professionals were also recorded. Such data are available on the Ministry of Health's website ${ }^{(4)}$.

It is estimated that $72 \%$ of the total individuals who evolved to deaths confirmed by COVID-19 in Brazil were over 60 years of age, and $70 \%$ had at least one risk factor ${ }^{(5)}$.

Despite the use of personal protective equipment, health professionals may become more vulnerable to infection by the virus than other individuals, perhaps due to the greater viral load to which they are exposed during their professional practice.

According to the Observatory of the Federal Nursing Council (COFEN), up to the first week of July 23,062 cases were recorded, with 238 deaths of nursing professionals possibly infected by SARS-CoV-2.

The DALY, Disability-Adjusted Life Years, corresponds to a healthy year of life that is lost or lived with disability and results from the combination of the Years of Life Lost due to premature death (YLL) and the Years Living with Disability (YLD) and can be used as an indicator to quantify and describe the burden of diseases, injuries and risk factors, making it possible to measure the impact of morbidity and mortality on the health status of the population ${ }^{(6)}$.

\section{OBJECTIVE}

To estimate the disease burden attributable to SARS-CoV-2 infection among nursing professionals in Brazil.

\section{METHOD}

\section{Ethical aspects}

The study incorporated in its design the basic references of Resolution No. 466/2012 of the National Health Council. In this sense, because it is an ecological study in which the data refer to groups of people and are of public domain, extracted from the website of the Nursing Observatory (http://observatoriodaenfermagem.cofen.gov.br/), therefore, there is no direct involvement of individuals or any possibility of identifying them or offering any type of risk and, therefore, causing no harm. or monetary and moral losses, there was no submission of the research protocol to the Research Ethics Committee.

\section{Design, place of study and period}

This is an observational study of the ecological type. In the description of the study, the checklist proposed by the Strengthening the Reporting of Observational Studies in Epidemiology (STROBE) was used.

Data collection was carried out from March 20 to July 5, 2020, in Brazil. Data were extracted from the website of the Brazilian Institute of Geography and Statistics (IBGE) for the year 2018, regarding the life expectancy of the Brazilian population, stratified by sex and age group. On the COFEN Nursing Observatory website, data were extracted regarding the incidence, prevalence and mortality, by age group, of nursing professionals infected by SARS-CoV-2 ${ }^{(7)}$.

\section{Population or sample}

The sample selection was intentional. All cases registered on the Nursing Observatory website that met the inclusion criteria were included: having been infected with SARS-CoV-2. Cases in which the professional category, sex and age group were not reported were excluded. The category of nursing assistant was grouped into the category of nursing technician; and that of obstetrician, grouped in the category of nurses.

\section{Study protocol}

An Excel $^{\circ}$ spreadsheet was used to organize the data after being downloaded directly from the IBGE website, about the life expectancy of the Brazilian population; and the Nursing Observatory website on the incident cases of COVID-19 in nursing professionals in Brazil.

In the spreadsheet, the following variables were inserted: sex, age, state of the Federation in which the professional resides, as well as the situation of each one, if they were alive or had died.

For determining the weight of the disease, it was considered the Global Burden of Disease study (GBD) 2017, taking into account the respiratory infection lower moderate ways, characterized as infectious diseases of the acute episode and moderate fever, aches and feeling of weakness, which cause some difficulty in daily activities, for which a load of 0.051 (0.032-0.074) was estimated. It should be noted that the weight of disability is a weight factor that reflects the severity of the disease on a scale from 0 (perfect health) to 1 (equivalent to death) ${ }^{(8)}$.

In the absence of more robust information about the duration and convalescence of the disease for individuals who had infection with SARS-CoV-2, a duration of 30 days ( 0.08 years) was considered reasonable for the analysis.) to estimate the Years of 
Living with Disability. The World Health Organization and the Brazilian Ministry of Health recommend half of that time (14 days) for home isolation, before returning to contact with other people.

\section{Analysis of results and statistics}

The analysis considered the distribution according to professional category, sex and age group; and the average standard life expectancy was calculated using the average age in each age group considering the Complete Mortality Tables for each sex and year of $2018^{(9)}$.

The prevalence of the disease, the Years of Life Lost (YLL) and the Years Lived with Disability (YLD) were estimated. The sum of these last two resulted in the number of Disability Adjusted Life Years (DALY).

The DALY was calculated by adding the mortality components (YLL), which refers to premature death, subtracting the life expectancy in the age group and the age at which the death occurred; and morbidity (YLD), multiplying the number of cases by the average duration of the disease ( 0.08 years) and the weight attributed to this condition (0.051).

The indicators were calculated for the exposed professional population, considering the number of professionals registered at the COFEN Nursing Observatory until July 5, 2020, stratified by age group, professional category and sex, for later calculation of the adjusted rates per thousand professionals.

The rates were calculated considering the numbers of DALYs or YLL or YLD, age group, sex and professional category, divided by the number of professionals by category infected and with confirmed diagnosis of COVID-19, in the analyzed records, multiplied by 10 thousand.

The confidence intervals were calculated by the Student's t test with an alpha of 0.05 , and the calculations were made using the free software JASP. No discount rates applied.

As this is an ecological study based on free access data available on the internet, which does not directly or indirectly involve a specific individual or allow identification, this research protocol was not submitted to ethical review.

\section{RESULTS}

We found, on the website of the Nursing Observatory ${ }^{1}$, accessed on July 5, 2020, a total of 21,767 case records of nursing professionals allegedly infected with SARS-CoV-2. Of this total, we excluded 14,566 records, because the diagnosis was not confirmed, or because the data were not complete, without identifying the professional category or age group to which the individual belonged. We included in the study, and considered as incident cases of COVID-19, 7,201 cases.

Of the total records analyzed, we identified 1,163 (16.1\%) records of cure of the disease, and 5,848 (81.30\%) records of professionals who were in quarantine. As for the death records, there were 190 (2.6\%) cases. Regarding gender, $83 \%$ of the records referred to female professionals.

1 http://observatoriodaenfermagem.cofen.gov.br/
Regarding the professional category, nursing technicians and assistants represented $70 \%$ of the total records analyzed, and the predominant age group was that of individuals aged between 31 and 40 years, representing $42.4 \%(n=3,055)$. Professionals over the age of 50 represented only $11.2 \%$ of the case records analyzed, as described in Table 1.

Table 1 - Characteristics of professionals with confirmed diagnosis for the new coronavirus - 2020

\begin{tabular}{lcc}
\hline & $\mathbf{n}$ & $\%$ \\
\hline $\begin{array}{l}\text { Professional Category } \\
\text { Nurses }\end{array}$ & 2,184 & 30 \\
$\quad$ Nursing technicians & 5,017 & 70 \\
Sex & & \\
Female & 5,963 & 83 \\
Male & 1238 & 17 \\
Age range & & \\
20-30 years & 1,312 & 18.2 \\
31-40 years & 3,055 & 42.4 \\
41-50 years & 2,030 & 28.2 \\
51-60 years & 682 & 9.5 \\
$>60$ years & 112 & 1.7 \\
Clinical Condition & & \\
Quarantine & & \\
Cured & 5,848 & 81.3 \\
Deaths & 1,163 & 16.1 \\
\end{tabular}

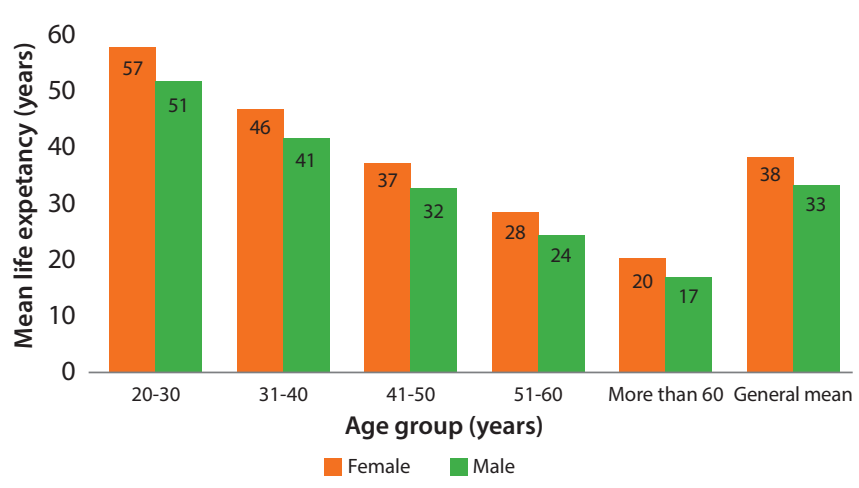

Source: IBGE, 2018.

Figure 1 - Distribution of the average life expectancy of professionals by sex and age group

The estimated life expectancy by age group is described in Figure 1. The average in the group was estimated at 38 years among women ( \pm 14.72 ) and 33 years among men ( \pm 13.54$)$.

Lethality, counting only confirmed cases of $\operatorname{COVID}(n=7,201)$, was $2.63 \%$. The lethality rate adjusted by a thousand professionals was estimated at $26 /$ thousand deaths. The prevalence of the disease was $0.31 \%$, considering the total number of nursing professionals registered with COFEN until May 5, 2020 (2,305,946). The coefficient of punctual prevalence of the disease per one hundred thousand professionals, considering the period of analysis (March 20 to July 5, 2020), was 312/one hundred thousand professionals.

In the total DALY counts for all categories, sex and age group, in just three and a half months after the beginning of the COVID-19 pandemic, period from March 20 to July 5, 2020, and from the first case registered by the Nursing Observatory, of a nursing professional infected by the virus, Brazilian nursing professionals lost $5,825.35( \pm 1,566.59)$ years of life adjusted for disability (DALY), with an average of 2,912.67 DALY (95\% Cl 2,872, 44-2,952.91). 
The total number of DALY among women was 4,020.42 years, representing $69 \%$ of the total DALY in nursing. The adjusted rate for a thousand professionals was 674.23/thousand among women and 1,457.94/thousand among men, although the female presence is the majority in Brazilian nursing ${ }^{(10)}$.

Figure 2 shows the distribution of years of life lost due to disability (YLD), prematurely (YLL) and adjusted for disability (DALY), by sex, professional category and age group, in which it is possible to observe how much nursing technicians in the females in the age group 31 to 40 years (curve with continuous line in bold) are impacted by the burden of infection by SARSCoV-2. However, it was among male professionals, both nurses and nursing technicians, those who had the greatest losses of years of life in the 41-50 age group (dashed line in bold). Among women, only nurses aged 41-50 years were the most impacted.

The DALY among male nursing technicians, aged $41-50$ years, was 450.95 years against 287.49 years in the age group 31-40 years. Among same-sex nurses, in the 41-50 age group, the DALY was 321.80 years against 205.10 years in the $31-40$ age group (Figure 2 ).

Among female professionals, in the group of nursing technicians, in the age group of 31-40 years, the estimated DALY was 793.44 years, against 743.57 years estimated in the age group of 41-50 years. Among nurses, in the age group 31-40 years, the estimated DALY was 327.35 years, against 334.30 years estimated in the $41-50$ years age group. Regardless of the professional category, the number of DALY among women was higher in all age groups, being, on average, $132 \%$ higher than the number of DALY among men (Figure 2).

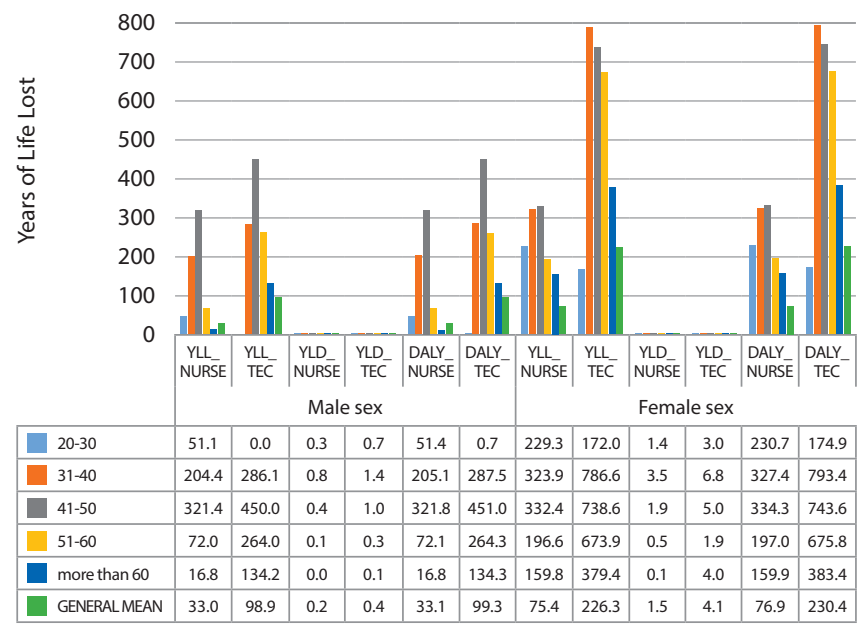

Figure 2 - Distribution of years of life lost due to disability, prematurely and adjusted for disability, considering gender and professional category as a nursing technician nurse, 2020

Table 2 shows the distribution of years of life lost due to premature death (YLL) and years lost due to disability (YLD). The years of life lost due to premature death (YLL) were higher among male nurses and nursing technicians, aged 41-50 years old, who lost, respectively, 204.4 and 286.1 years of life prematurely. Therefore, among nursing technicians, the number of years of life lost due to premature death was $39 \%$ higher than among nurses.

Still in relation to male professionals, the number of years of life lived with disability (YLD) was higher in the age group of 31-40 years, being 0.8 years among nurses and 1.4 among nursing technicians.
Therefore, among nursing technicians, the number of years lived with disabilities was $75 \%$ higher than among nurses (Table 2 ).

Among female professionals, the years of life lost due to premature death (YLL) were higher among nurses aged $41-50$ years (332.4 years); and among nursing technicians, aged $31-40$ years (786.6 years). Nursing technicians lost $136 \%$ more lives due to premature death than nurses. Regarding the years lived with disability (YLD), the highest numbers were observed in the age group of 31-40 years, both among nurses and among nursing technicians, who lost, respectively, 3.5 and 6.8 years. This represents a $94 \%$ higher YLD percentage among nursing techniques (Table 2 ).

Table 2 - Distribution of years of life lost due to premature death and years lived with disability according to sex, age group and professional category, 2020

\begin{tabular}{lcccccccc}
\hline \multirow{2}{*}{ Age group } & \multicolumn{4}{c}{ Male Sex } & \multicolumn{4}{c}{ Female Sex } \\
& YLL & YLL & YLD & YLD & YLL & YLL & YLD & YLD \\
& NURSE & TEC & NURSE & TEC & NURSE & TEC & NURSE & TEC \\
\hline $20-30$ & 51.1 & 0.0 & 0.3 & 0.7 & 229.3 & 172.0 & 1.4 & 3.0 \\
$31-40$ & 204.4 & 286.1 & 0.8 & 1.4 & 323.9 & 786.6 & 3.5 & 6.8 \\
$41-50$ & 321.4 & 450.0 & 0.4 & 1.0 & 332.4 & 738.6 & 1.9 & 5.0 \\
$51-60$ & 72.0 & 264.0 & 0.1 & 0.3 & 196.6 & 673.9 & 0.5 & 1.9 \\
More than 60 & 16.8 & 134.2 & 0.0 & 0.1 & 159.8 & 379.4 & 0.1 & 4.0 \\
MEAN & 33.0 & 98.9 & 0.2 & 0.4 & 75.4 & 226.3 & 1.5 & 4.1 \\
\hline
\end{tabular}

Table 3 shows the proportional contribution of the number of years of life lost due to premature death (YLL) and disability (YLD) in the number of estimated DALY, considering the professional category, sex and age group.

Only among male nursing technicians and in the 20-30 age group, the YLD had a greater proportional contribution in DALY, being responsible for $100 \%$. In all other cases, the impact of the YLL was greater and, on average, greater than $98 \%$.

The contribution proportion of the number of years of life lost due to premature death (YLL) in the total of DALY among male professionals was 99.58, whereas, among female professionals, this proportion was $98,18 \%$. In the general DALY $(5,825.35)$, considering all professionals, regardless of professional category, sex or age group, the contribution of YLL was $98.88 \%$.

Table 3 - Distribution of the percentages of contributions of years of life lost due to premature death and years lived with disability, in the calculation of years of life lost adjusted for disability, by professional category and age group, 2020

\begin{tabular}{|c|c|c|c|c|c|c|c|c|}
\hline \multirow{3}{*}{ Age group } & \multicolumn{4}{|c|}{ Nurses } & \multicolumn{4}{|c|}{ Nursing Technicians } \\
\hline & \multicolumn{2}{|c|}{ Male } & \multicolumn{2}{|c|}{ Female } & \multicolumn{2}{|c|}{ Male } & \multicolumn{2}{|c|}{ Female } \\
\hline & YLL & YLD & YLL & YLD & YLL & YLD & YLL & YLD \\
\hline $20-30$ & 99.4 & 0.6 & 99.4 & 0.6 & 0.0 & 100.0 & 98.3 & 1.7 \\
\hline $31-40$ & 99.6 & 0.4 & 98.9 & 1.1 & 99.5 & 0.5 & 99.1 & 0.9 \\
\hline $41-50$ & 99.1 & 0.1 & 99.4 & 0.6 & 99.8 & 0.2 & 99.3 & 0.7 \\
\hline $51-60$ & 99.9 & 0.1 & 99.8 & 0.2 & 99.9 & 0.1 & 99.7 & 0.3 \\
\hline More than 60 & 99.9 & 0.1 & 99.9 & 0.1 & 100.0 & 0.0 & 99.0 & 1.0 \\
\hline Mean & 99.5 & 0.5 & 98.1 & 1.9 & 99.6 & 0.4 & 98.2 & 1.8 \\
\hline
\end{tabular}

\section{DISCUSSION}

Four months after the registration of the first confirmed case of a nursing professional infected with coronavirus in Brazil, the number of new cases continues to increase. Rio de Janeiro leads 
the ranking of states with the largest number of nursing professionals who work to combat COVID-19 infected by the virus. The state accumulates 34 deaths and 1,664 infected. São Paulo, in second place, has 34 fatal victims and 1,251 contaminated $^{(11-12)}$.

A study that analyzed 81 deaths in a group of 6,427 nursing professionals diagnosed with COVID-19 from March 20 to May 5 found - using data obtained at the Nursing Observatory and the same weight and duration for recovery attributed to the disease, the same methodology and analysis techniques adopted in this study - that Brazilian nursing lost an average of $562.51(95 \% \mathrm{Cl}$ 495.24-629.79) Lost Life Years Adjusted by Disability (DALY), which, for the short period analyzed, can be considered a significant loss ${ }^{(10)}$.

Comparing these results, it is possible to see a substantial increase in the number of DALYs, from 562.51 (95\% Cl 495.24-629.79) to $2,912.77$ ( $95 \% \mathrm{Cl} 2,876.49-2,948.86$ ) in the present study, the which represents an increase of $417.80 \%$ in the number of DALY. It is important to highlight that, in our study, the number of records analyzed was $11.75 \%(n=7,201)$ greater than that of the study cited.

The increasing trend in the number of DALY reveals the weight of SARS-CoV 2 infection among nursing professionals in Brazil during this pandemic. Such a high increase in the rate of DALY gives us the dimension of the impact of this disease on mortality and disability, especially if we consider that it is a disease of acute evolution. The increase in the number of DALYs due to SARSCoV-2 infection among nursing professionals helps to explain the reduction in the number of professionals on the front lines of combating the pandemic, as well as the increase in absenteeism.

High rate of infection by the new coronavirus among health professionals (25\%), well above those seen in China (4\%) and Italy (15\%), was found among professionals in a study conducted in Rio de Janeiro, one of the states most affected by the disease ${ }^{(12-14)}$.

Regarding the 190 deaths registered and reported by the Nursing Observatory (COFEN, 2020) in the analyzed period, it was found that the number of YLLs remains high, representing, on average, more than $98 \%$ of the total number of DALYs in the studied population. Only among nursing technicians aged 20-30 years, the years of life lived with disability (YLD) were proportionally greater than the years of life lost due to premature death, when compared to the numbers found by Silva et al. (2020). In this group of professionals, YLD represented $100 \%$ of the estimated DALY number. This shows that, although the number of deaths may be lower among younger professionals, the damage and sequelae caused by the disease can seriously compromise the quality of life of these individuals.

It is not yet possible to accurately estimate the fatality rate, as many cases registered at the Nursing Observatory have not yet had positive or negative outcomes in terms of cure or death. The fatality rate can still vary due to demographic, socioeconomic factors, testing capacity and the conditions of service provision, especially the intensive care unit (ICU), of the health systems of each state, directly impacting the years of life lost due to premature death (YLL) and, consequently, on DALY. Although the stratifier DALY by states of the Federation has not been estimated, what can be seen is that SARS-CoV-2 infection has shown indications of being a disease that, among nursing professionals, has been shown to be moderate to high severity, mainly in terms of fatality.

The figures confirm the severity of the disease. In the group of professionals over the age of 50, for example, regardless of professional category and gender, the proportion of YLL in the number of DALY was at least $99.7 \%$, showing how vulnerable this group is. Although the measures for removal from work activities are being indicated only for those professionals over the age of 60 years and despite the fact that professionals in the age group 31-40 years have presented the highest number of DALY, it is necessary to take a look more careful with professionals over 50 years old.

The high contribution of YLL to the burden of COVID-19 can be attributed to the short survival time, especially in the most severe form of the disease, when the patient progresses to severe acute respiratory syndrome (SARS), whose lethality is high.

The data can help to rethink the measures used to reduce preventable or reducible deaths, which can be prevented through effective actions by health services, such as prioritizing the removal not only of those over the age of 60 , but seeking to analyze each case among professionals aged 50 and over. However, given the increase in absenteeism, it may not be possible for many health systems and services to reduce the age limit to keep these professionals away from care, as a measure to reduce the risk of death among them, which is understandable.

In view of the reality imposed by the pandemic, it is possible to note the different ways in which the health crisis caused by the disease can affect the economy. The high number of DALY found in the present study may contribute to the increase in absenteeism and decrease in work productivity, due to the magnitude of the physical and psychological effects and all the symptoms of the disease, whose time for the total recovery of the professional may be long, varying between 8 to 17 months, considering the DALY rates per thousand professionals, which was 1,457.94 DALY among men and 674.23 DALY among women ${ }^{(15)}$.

Proportionally, the difference in the number of DALY and the consequent impact of SARS-CoV-2 infection among female health professionals was a fact that drew a lot of attention, although nursing is a profession composed mainly of women. On average, considering the different age groups, the number of DALYs among women was $132 \%$ higher than among men.

In Brazil, women have long been responsible for family income. As nursing is a profession whose workforce has a female majority, it is possible that many nurses and nursing technicians took over the support of the home, especially in this pandemic moment, when many jobs were lost. But they, in addition to their work activities, remain in charge of domestic activities.

The work rhythm of nursing workers, as well as the excessive workload performed by these professionals, in addition to the dimensioning of staff that is almost always inadequate and the difficulties in interpersonal relationships, must be considered determining factors for professional illness, which in itself can cause losses in quality of life, further impacting the number of DALY. However, among female nursing professionals, problems can be aggravated by discrimination in work relationships and the overload of responsibilities in domestic work ${ }^{(16)}$.

\section{Study limitations}

The power to extrapolate the results is limited, since the research was based on secondary data provided by the Nursing Observatory of the Federal Nursing Council (COFEN). Still, it is 
possible that there is underreporting of cases, since notification at the Nursing Observatory depends on the initiative of the professional or his family. The large amount of incomplete data must also be considered, which has significantly reduced the number of case records included in the study.

Therefore, incomplete data about the sociodemographic characteristics related to the cases registered at the Nursing Observatory and related to the outcomes (death and infection by SARS-CoV-2) can skew the results found in the study.

The fact that there is still no reference on the weight of SARSCoV-2 infection, which is why the weight attributed to seasonal flu was used in its moderate form and not in its severe form, as well as the uncertainties about the time needed to full recovery from the disease are limitations that also need to be considered.

\section{Contributions to the field of nursing, health or public policy}

The results presented in this study may support intervention strategies inherent to the health of nursing workers and other health professionals who are also impacted by this disease. These results will be brought to the attention of the competent authorities and researchers, so that they can serve as a basis for, based on their different competencies, to focus on the factors that may be contributing to this high number of DALY among these professionals. - factors that should, therefore, be the object of attention and concern.

The study brings contributions to the field of nursing both from a scientific perspective, given the use of new research designs, further expanding the scope of knowledge production in the area, and from the perspective of human resource management, care planning and formulation of public policy.

\section{FINAL CONSIDERATIONS}

The COVID-19 pandemic is being a unique opportunity for each of us to perceive and reflect on the weaknesses in our country, especially with regard to the health of health professionals.

In view of the need to guarantee quality and quantity of health professionals in the front line to combat the pandemic of COVID-19 in Brazil, in order to increase the chances of reducing the negative impacts of this disease on society, it is essential that managers take notice and look at the numbers presented in this study, in order to develop strategies for promoting the health of these health sector workers, which should be prioritized.

The study identified different load patterns of SARS-CoV-2 infection with respect to all variables analyzed, considering the professional categories, sex and age group among nursing professionals in Brazil. The burden of disease among these professionals due to infection by SARS-CoV-2 follows an upward trend and has a greater impact on younger people. However, new studies need to be developed to better analyze the trend of the evolution of the disease burden while the pandemic lasts.

The DALY numbers found point to important differences in the distribution by age, professional category and, above all, sex. In this sense, managers should also schedule activities that prioritize women's health policies within employing institutions.

\section{REFERENCES}

1. Wang C, Horby PW, Hayden FG, Gao GF. A Novel Coronavirus Outbreak of Global Health Concern. Lancet. 2020;395:470-473. https://doi. org/10.1016/S0140-6736(20)30185-9

2. Guan WJ, Ni ZY, Hu Y. Clinical characteristics of coronavirus disease 2019 in China. N Engl J Med. 2020; 382:1708-20. https://doi.org/10.1056/ NEJMoa2002032

3. Góes LGB, Zerbinati RM, Tateno AF. Epidemiologia típica de infecções por vírus respiratórios em uma favela brasileira. J Med Virol. 2019;1(6). https://doi.org/10.1002/jmv.25636

4. Mistério da Saúde (BR). Mais de 970 mil profissionais de saúde cadastrados para atuar no combate à Covid-19. Brasília. Sexta, 12 de Junho de 2020[Internet]. 2011 [cited 2020 Jul 5]. Available from: https://antigo.saude.gov.br/noticias/ agencia-saude/47050-mais-de-970-mil-profissionais-de-saude-cadastrados-para-atuar-no-combate-a-covid-19

5. Ministério da Saúde (BR). Secretaria de Vigilância em Saúde. Boletim Epidemiológico Especial - 13 | SE 11 de 19 de abril de 2020[Internet]. 2020 [cited 2020 Jul 5]. Available from: https://portalarquivos.saude.gov.br/images/pdf/2020/April/21/BE13---Boletim-do-COE.pdf.

6. Murray CJ. Quantifying the burden of disease: the technical basis for disability-adjusted life years. Bull World Health Organ [Internet]. 1994 [cited 2020 Jul 5];72(3):429-45. Available from: https://www.ncbi.nlm.nih.gov/pmc/articles/PMC2486718/pdf/bullwho00414-0105.pdf

7. Fletcher RH, Fletcher SW, Fletcher GS. Epidemiologia clínica: elementos essenciais. 5a. Ed. Porto Alegre: Artmed, 2014. 280 p.

8. Global Burden Disease 2017. Disease and Injury Incidence and Prevalence Collaborators. Global, regional, and national incidence, prevalence, and years lived with disability for 354 diseases and injuries for 195 countries and territories, 1990-2017: a systematic analysis for the Global Burden of Disease Study 2017. Lancet. 2018; 392:1789-858. https://doi.org/10.1016/S0140-6736(18)32279-7

9. Instituto Brasileiro de Geografia Estatística (IBGE). Tábua de Mortalidade [Internet]. 2018 [cited 2020 Jul 5]. Available from: https://www.ibge. gov.br/estatisticas/sociais/populacao/9126-tabuas-completas-de-mortalidade.html?=\&t=resultados.

10. Machado MH, Wermelinger M, Vieira M, Oliveira E, Lemos W, Aguiar Filho W, et al. Perfil da enfermagem no Brasil: relatório final, Rio de Janeiro. Enferm Foco [Internet]. 2016[cited 2020 Jul 5];(2/4):15-34. Available from: http://revista.cofen.gov.br/index.php/enfermagem/article/viewFile/687/297

11. Silva RCL, Silva C, Machado D, Peregrino A, Marta C, Pestana L, et al. Anos de vida perdidos ajustados por incapacidade (DALY) entre os profissionais de enfermagem devido a infecção pelo SARS-CoV-2 no Brasil. Scielo Preprints. 2020. https://doi.org/10.1590/ SciELOPreprints.414 
12. Azevedo AL. Coronavírus atinge até $25 \%$ de profissionais de saúde no Rio. O Globo, Seção Sociedade, Rio de Janeiro [Internet]. 2020 [cited 2020 Jul 5]. Available from: https://oglobo.globo.com/sociedade/coronavirus/coronavirus-atinge-ate-25-dos-profissionais-de-saude-no-rio-1-24357939

13. Koh D. Occupational risks for COVID-19 infection. Occupation Med (Oxford, England). 2020;70(1):3-5. https://doi.org/10.1093/occmed/ kqaa036

14. Anelli F, Leoni G, Monaco R. Italian doctors call for protecting healthcare workers and boosting community surveillance during covid-19 outbreak. BMJ. 2020;368:m1254. https://doi.org/10.1136/bmj.m1254

15. Monteiro WM, Brito SJD, Baía DS, Melo GC, Siqueira AM, Val F, et al. Driving forces for COVID-19 clinical trials using chloroquine: the need to choose the right research questions and outcomes. Rev Soc Bras Med Trop. 2020;53:e2020. https://doi.org/10.1590/0037-8682-0155-2020

16. Ministério da Saúde (BR). Secretaria de Atenção à Saúde. Departamento de Ações Programáticas Estratégicas. Política Nacional de Atenção Integral à Saúde da Mulher: Princípios e Diretrizes. 2. reimpr. Brasília: Editora do Ministério da Saúde (Série C. Projetos, Programas e Relatórios) [Internet]. 2011 [cited 2020 Jul 5]. Available from: https://bvsms.saude.gov.br/bvs/publicacoes/politica_nacional_mulher_ principios_diretrizes.pdf 